\title{
Characteristics of Stable Isotopes in an Inland Lake and Their Implications for Water Management in Northwestern China
}

\author{
Honghua Zhou', Weihong Li' ${ }^{1}$, Yun Wang' ${ }^{2}$ Zhaoxia Ye' \\ ${ }^{1}$ State Key Laboratory of Desert and Oasis Ecology, Xinjiang Institute of Ecology and Geography, Chinese \\ Academy of Sciences, Urumqi, China \\ ${ }^{2}$ Xinjiang Normal University, Urumqi, China \\ Email: zhouhh@ms.xjb.ac.cn
}

Received 10 March 2016; accepted 24 May 2016; published 27 May 2016

Copyright (C) 2016 by authors and Scientific Research Publishing Inc.

This work is licensed under the Creative Commons Attribution International License (CC BY). http://creativecommons.org/licenses/by/4.0/

(c) (i) Open Access

\begin{abstract}
Bosten Lake is the largest inland freshwater lake in China, functioning as a critical control and allocation facility for agricultural, industrial, ecological and social development in southern Xinjiang in northwestern China. The distribution of stable isotopes, spatial and temporal variations of $\delta^{18} 0$, and hydrograph separation of Bosten Lake and its principal recharge rivers-the Kaidu River and the Huangshuigou River-were analyzed using isotope composition. Hydrograph separation indicated that Bosten lake water comprised four components as follows: river runoff, groundwater, agricultural and industrial drainage, and local precipitation. Their contributions were $31 \%, 35 \%$, $\mathbf{2 5 \%}$, and $\mathbf{9 \%}$, respectively. Irrigation drainage and industrial wastewater, enriched high TDS, were the main factors affecting the water quality of Bosten Lake. The $\delta^{18} 0$ of lake water, which was significantly reduced compared with river water, remained below the local meteoric water line (LMWL), indicating strong evaporation in the lake, especially during summer. The spatial and temporal distribution of $\delta^{18} 0$ exhibited slow water circulation in the lake. Both the Kaidu River and the Huangshuigou River depend on alpine precipitation and glacier snow, especially the Kaidu River, where ice-snow-melt water accounts for $43 \%$ of the river runoff. These rivers are sensitive to climate change. The Bosten Lake inflows would be reduced by the decrease in river runoff and groundwater under future climate change. To improve water quality and reduce evaporative loss, the amount of wastewater should be strictly restricted by local government, and water diversions from Bosten Lake should be concentrated between May and September.
\end{abstract}

\section{Keywords}

Isotope Composition, Spatial and Temporal Variation, Hydrograph Separation, Bosten Lake, 


\section{Arid Area}

\section{Introduction}

Water is the most essential resource for ecological, social and economic development, as well as biological survival [1]. Water resources management encounters the problem of balancing the need for water between ecological protection and economic development, especially for the arid regions of the world which suffer from water scarcity [2]. Therefore, an understanding of hydrological processes and water cycle evolution is important for addressing questions relating to water resource management and related environmental issues, for which it is necessary to clarify a comprehensive understanding of the mechanisms and pathways of water traveling from terrestrial to aquatic systems [3]. However, traditional hydrological observation is unavailable to the few gauged or ungauged regions [4], especially for the arid region with extreme climate conditions of northwestern China, where there are few gauges despite accounting for more than one-fourth of the national area. Isotope traces have been a widely useful environmental tracer in studying hydrological processes. The stable isotope ratios of hydrogen and oxygen of water samples can provide essential information for the source of water and the interaction between surface and groundwater within a given watershed [5]-[8] due to the stability of the isotopic composition of water after mixing has occurred [9].

For the hydrograph separation analysis based on stable isotopes, the multi-component model was widely used to compute the contributions of different components of the water system [10]. Since the 1980s, numerous isotopic tracing studies have been used on hydrological processes in watersheds around the world. Taking China as an example, the water dynamics of many river basins, such as the Yellow River [11], Heishui River [9], Tibetan Plateau [12], Tarim River [8], Tizinafu River [3], and Heihe River [7], have been studied using isotopes. However, no study has been conducted on Bosten Lake, where the main water source is not clearly understood. Bosten Lake, which is the sole water source for the Kongque River, is the largest inland fresh water lake in China and provides multiple functions, including water resources regulation for controlling drought or flooding, field irrigation, and industrial, municipal and rural water supplies in the Kongque River Basin, as well as environmental protection in the Kongque River Basin and the lower reaches of the Tarim River. The objectives of this study were as follows: 1) to clarify the characteristics of $\delta \mathrm{D}$ and $\delta^{18} \mathrm{O}$ of the water sources composing Bosten lake; 2) to investigate the temporal and spatial variations in $\delta \mathrm{D}$ and $\delta^{18} \mathrm{O}$ of Bosten Lake; 3) to calculate the proportion of runoff, precipitation, groundwater, drainage, and snow-glacier-melt water in Bosten Lake and 4) to identify implications for hydrograph separation for water management of the arid lake in the future. This study will add to our understanding of the features of water isotopes in arid areas and provide insight into water resources management in the lakes of arid regions.

\section{Study Area}

Bosten Lake $\left(86^{\circ} 19^{\prime}-87^{\circ} 28^{\prime} \mathrm{E}, 41^{\circ} 44^{\prime}-42^{\circ} 14^{\prime} \mathrm{N}\right)$ is an inland lake located in northwestern China (Figure 1). Bosten Lake functions as a central water control and allocation facility for the Bosten Basin comprising the Kaidu River Basin and the Kongque River Basin, regulating droughts and floods and providing irrigation and drinking water. This lake is also an important fishery and source of reeds for Xinjiang Province. Given the importance of Bosten Lake to the regional economy, society, environment and climate, Bosten Lake has been incorporated into the "Lake Governance Agenda in the 21st century" and the "Program of 1311 environment protection action in Xinjiang" as an important water resource of the Xinjiang Water Resource Comprehensive Management Plan. Moreover, the lake became one of the first lakes of the national program "Pilot projects to protect the ecological environment of lakes of China" in 2012.

The Bosten Lake Basin, which is approximately $13.34 \times 10^{4} \mathrm{~km}^{2}$, features abundant light and heat, and scarce precipitation. The Bosten Lake Basin has a mean annual temperature of $8.4^{\circ} \mathrm{C}$ and mean annual total precipitation of $68.2 \mathrm{~mm}$. The lake is approximately $55 \mathrm{~km}$ long from east to west and $20 \mathrm{~km}$ wide from south to north. Bosten Lake discharges to the Kongqi River through a pump. Its contributing rivers include the perennial Kaidu River and the seasonal Huangshuigou and Qingshui Rivers, which originate from the Tianshan Mountain and are fed mainly by glacier melt and snowmelt from the alpine zone, as well as by precipitation from the mountain 
zone. There is no flow from the Qingshui River into Bosten Lake because its lower reaches have been dried up since 2010.

\section{Sampling and Methods}

\subsection{Sampling and Data Collection}

Forty-eight lake water sample sites were established around Bosten Lake. Sixteen surface water sample sites were established along the Kaidu River, and seven surface water sample sites were established along the Huangshuigou River. Eleven groundwater sample sites were established, including seven groundwater sample sites along the rivers and four groundwater sample sites near the lake. Groundwater samples were collected from groundwater wells that were more than $20 \mathrm{~m}$ depth. One ice-snow-melt sample site was located in a snow pack of an alpine mountain in Bayinbuluke, and one agricultural and industrial wastewater sample site was placed close to the main sewage outlets to the Bosten Lake. Water samples were collected from these sample sites in January, March, June, July, August, October and November 2011. Precipitation samples were obtained from (by event) the Bayinbuluke weather station (in the alpine mountain) and the Yanqi weather station (close to Bosten Lake) from January to October 2011. The sampling site locations are illustrated in Figure 1.

Once the samples were collected in dry and clear $5 \mathrm{ml}$ glass blue bottles, they were stored in a refrigerator $\left(4^{\circ} \mathrm{C}\right)$ as soon as possible until analysis. In addition, we collected another sample at each sample site to analyze total dissolved solids (TDS) by weighing.

\subsection{Isotope Analysis and Model Description}

Oxygen-18 and deuterium in the water samples were measured at the State Key Laboratory of Desert and Oasis Ecology, Xinjiang Institute of Ecology and Geography, Chinese Academy of Sciences using a laser absorption water isotope spectrometer analyzer (Model DLT-100, Los Gatos Research Inc.). Isotopic concentrations were expressed as the difference between the measured ratios of the sample and compared with the measured reference ratio of standard mean ocean water (SMOW), expressed using $\delta$ notation [13]:

$$
\begin{aligned}
\delta^{18} O_{\text {SAMPLE }} & =\left\{\frac{\left({ }^{18} O /{ }^{16} O\right)_{\text {SAMPLE }}}{\left({ }^{18} O /{ }^{16} O\right)_{\text {SMOW }}}-1\right\} \times 10^{3} \\
\delta H_{\text {SAMPLE }} & =\left\{\frac{\left({ }^{2} H /{ }^{1} H\right)_{\text {SAMPLE }}}{\left({ }^{2} H /{ }^{1} H\right)_{\text {SMOW }}}-1\right\} \times 10^{3}
\end{aligned}
$$
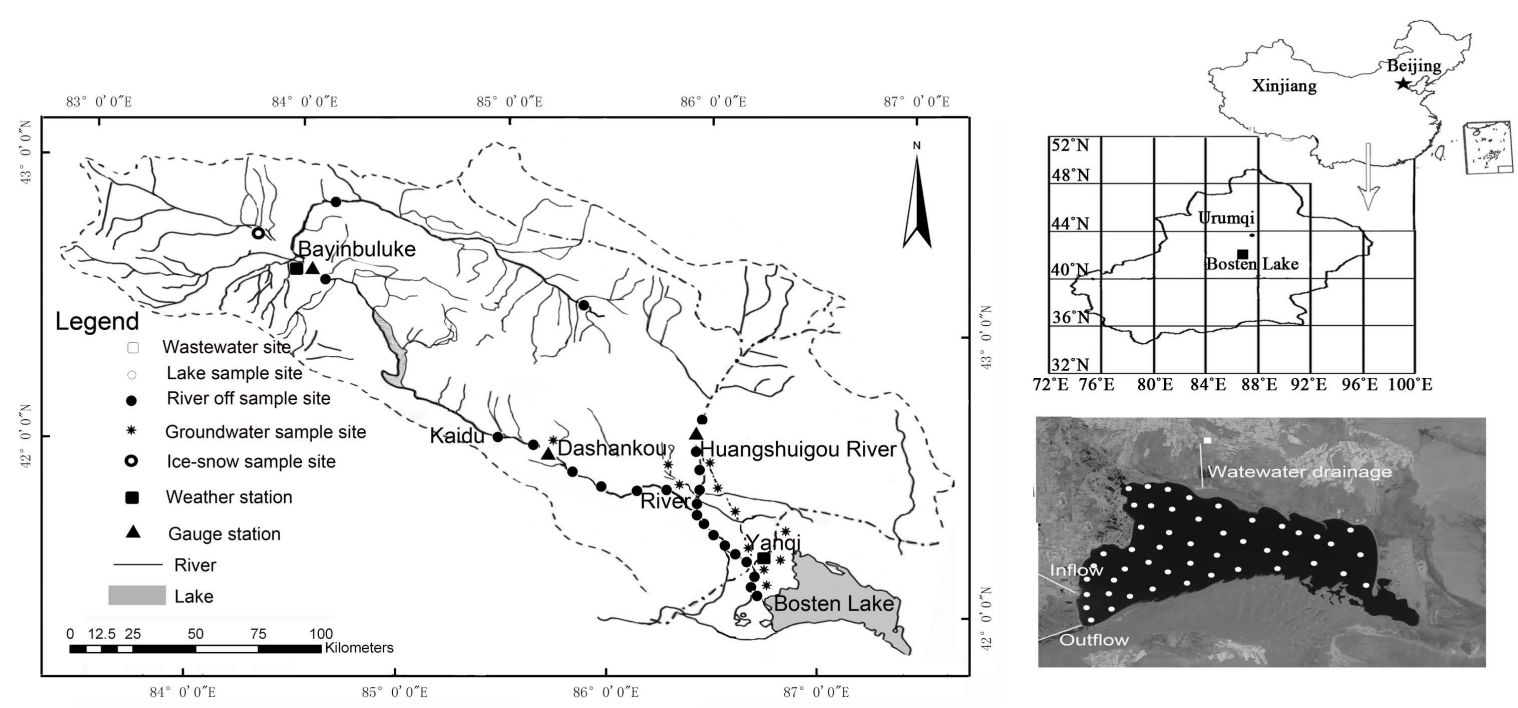

Figure 1. Sketch map of the study area and sample sites. 
The analytical errors for the entire procedure were $\pm 0.1 \%$ and $0.3 \%$ for $\delta^{18} O$ and $\delta D$, respectively.

For hydrograph separation, a widely used multi-component method, we used the following the analysis equation [10]:

$$
Q_{t}=\sum_{m=1}^{n} Q_{m}, Q_{t} C_{t}^{j}=\sum_{m=1}^{n} Q_{m} C_{m}^{j}, j=l, \cdots, k
$$

where $Q_{t}$ is the total lake water discharge; $Q_{m}$ is the discharge of component $m$; and $C_{j m}$ is the tracer $\mathrm{j}$ incorporated into the component $m$. $C_{j m}$ should be constant during the calculation period, such as a rainfall-runoff process, and this value should be different between each component. A steady-state model adequately represents the watershed conditions.

In this study, $\delta^{18} \mathrm{O}$ and TDS were used as the tracers for the isotopic hydrograph separation. The runoff from the Kaidu River and the Huangshuigou River can be separated into the three components (ice-snow-melt, alpine precipitation and groundwater), and the lake water can be separated into four components (river runoff, lake precipitation, groundwater, and agricultural and industrial drainage).

\section{Results and Discussion}

\subsection{Isotopic Characteristics of Water Sources in the Rivers and Bosten Lake}

Comparing the stable isotope $\left(\delta^{18} \mathrm{O}\right.$ and $\left.\delta^{2} \mathrm{H}\right)$ of different water samples using the global meteoric water lines (GMWL) and local meteoric water lines (LMWL) was useful for clarifying the water source and isotopic fractionation for the study of regional hydrological processes [13] [14]. Because isotopic data on precipitation in Bosten Lake Basin (including Kaidu River Basin and Kongque River Basin) are insufficient to form LMWL, we used the data from the Urumqi weather station $\left(43.78^{\circ} \mathrm{N}, 87.62^{\circ} \mathrm{E}, 918 \mathrm{~m}\right.$ above sea level), which is also located on Tianshan Mountain, to construct the LMWL. The isotopic data on the precipitation from the Urumqi weather station were collected from the Global Network of Isotopes in Precipitation (GNIP) from 1986 to 2003 (the construction process see [1].

The $\delta^{18} \mathrm{O}$ values of the water samples collected along the Kaidu River ranged from $-8.99 \%$ to $13.33 \%$, with a mean of $-10.14 \%$. The $\delta \mathrm{D}$ values ranged from $-66.02 \%$ to $90.42 \%$, with a mean of $72.36 \%$ (Figure 2 (a)). The $\delta^{18} \mathrm{O}$ values of the Huangshuigou River ranged from $-9.13 \%$ to $-10.82 \%$, with a mean of $-9.83 \%$. The $\delta \mathrm{D}$ values ranged from $-56.96 \%$ to $74.12 \%$, with a mean of $-64.13 \%$ (Figure 2 (a)). These values fit with or were above the GMWL and LMWL (Figure 2(a)), indicating that the runoff of the Kongque River and the Huangshuigou River originated from ice-snow-melt water and precipitation in the alpine mountain at low tempera-

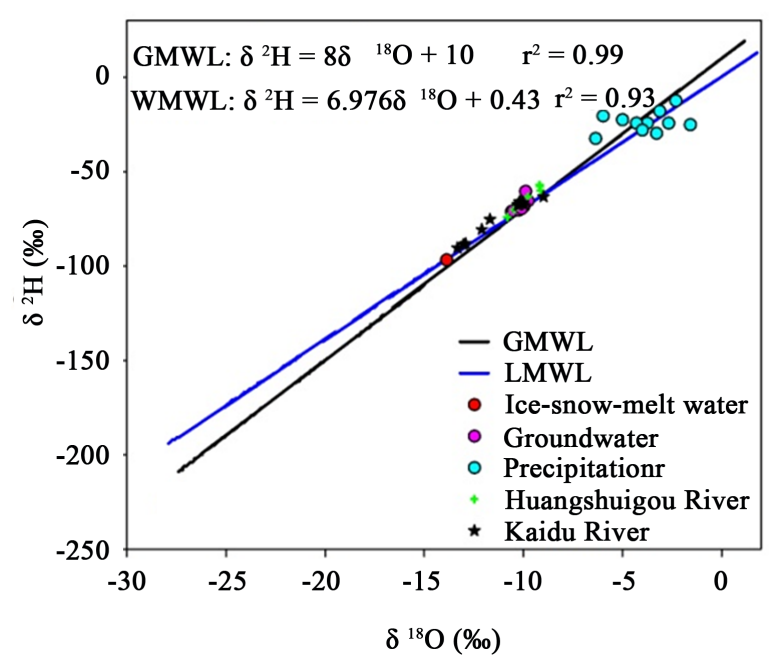

(a)

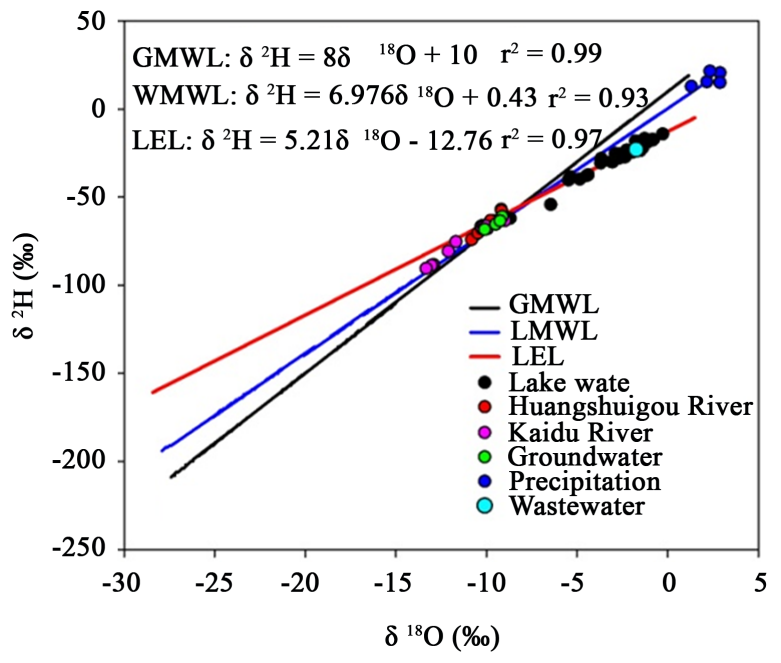

(b)

Figure 2. Distribution of isotopes incorporated in the river water, lake water, groundwater, precipitation, ice-snow-melt water, and wastewater relative to the global and local meteoric water line (GMWL and LMWL, respectively), as well as the local evaporation line (LEL). 
ture and absolute air moisture content and that little evaporation was involved in the flows in the Kaidu River and the Huangshuigou River. Simultaneously, the isotope values of the groundwater samples had been covered by the river water samples, demonstrating that the river flow and groundwater had a similar water source and that the groundwater recharged the runoff [3] [10]. The differences in $\delta^{18} \mathrm{O}$ and $\delta \mathrm{D}$ in the precipitation samples from individual rainfall events were significant at the local area. Reference [14] and Reference [10] suggested that the isotope composition of precipitation is typically controlled by air temperature, moisture and precipitation history. In this study, the precipitation samples were collected from different months in 2011.Therefore, these samples were potentially affected by the temperature.

The $\delta^{18} \mathrm{O}$ values of the surface water samples collected around Bosten Lake ranged from $-0.28 \%$ to $9.61 \%$, with an average of $-4.10 \%$. The $\delta \mathrm{D}$ values ranged from $-14.12 \%$ o to $-66.25 \%$, with an average of $-29.15 \%$. The stable isotope values of the water from Bosten Lake were increased compared with the water from the Kaidu River and Huangshuigou River runoff (Figure 2(b)), suggesting that the isotope composition was significantly enriched in the lake and depleted in the rivers [1]. The water samples of Bosten Lake were significantly below the LMWL and GMWL but fit the local evaporation line (LEL), which was regressed by the below equation using the 48 water samples from Bosten Lake:

$$
\delta^{2} H=5.20 \times \delta^{18} O-12.16, \quad r^{2}=0.96 .
$$

These data indicate that significant evaporation processes occurred in Bosten Lake [15]. Reference [16] demonstrated that an average of approximately $8.74 \times 10^{8} \mathrm{~m}^{3} / \mathrm{yr}$, which was greater than $40 \%$ of Bosten lake inflow, was being depleted by evaporation every year. In addition, most of the isotope composition values of the groundwater samples overlapped with those of the river samples, suggesting a very close relationship between groundwater and runoff. Moreover, the agricultural and industrial wastewater overlapped the lake water, proving that all of the agricultural and industrial waters were from Bosten Lake. However, the groundwater was similar to the river runoff mainly originating from the alpine precipitation and ice-snow-melt water. Additionally, the isotopic composition of river water, groundwater, agricultural and industrial wastewater, and precipitation in the Yanqi Basin lay near the LEL, indicating that all four water sources recharge to Bosten Lake. In particular, the samples in the intersection of the LEL with the LMWL, groundwater and river water corresponded to the average isotopic composition of the water entering the lake [17].

\subsection{Spatial and Temporal Variability of Water Isotope in Bosten Lake}

For any given lake, $\delta^{18} \mathrm{O}_{\text {lake }}$ and $\delta^{2} \mathrm{H}_{\text {lake }}$ will rely on the hydrological balance between inputs (groundwater, precipitation, surface and stream inflows) and outputs (groundwater loss, evaporation, surface and stream outflows) [18] [19]. Therefore, the spatial and temporal characteristics of the isotope composition in lakes must be identified to illuminate the water cycle, such as water sources, residence time of water and evaporation, to operate water management. $\delta^{18} \mathrm{O}$ was used in this study to analyze the spatial and temporal variability due to its enhanced stability compared with $\delta \mathrm{D}$ [20]. A contour plot of $\delta^{18} \mathrm{O}$ in Bosten Lake water was made using surfer V8.0 software and the 48 samples collected around the whole river in July 2011 (Figure 3). The $\delta^{18} \mathrm{O}$ values of the Bosten Lake surface water samples ranged from $-0.27 \%$ to $-9.99 \%$ with an average of $-3.53 \%$. The water level of Bosten Lake was relatively low (the deepest level is $16 \mathrm{~m}$ ); most of the $\delta^{18} \mathrm{O}$ values of the water samples varied around $-3 \%$ - to $2 \%$. The low $\delta^{18} \mathrm{O}$ values of the water were concentrated in the southwestern corner where the river recharged to the lake. The inflow from the river diluted the lake water, thus resulting in lower $\delta^{18} \mathrm{O}$ in the southwestern lake. The high $\delta^{18} \mathrm{O}$ values were concentrated in the northwestern corner where the agricultural and industrial wastewater, especially for the irrigation drainage, recharged into the lake. The wastewater, which mixed with surface water and groundwater after use, experienced a strong evaporation, finally resulting in its significantly enriched isotope composition. Generally, low $\delta^{18} \mathrm{O}$ diffused from south to west, and high $\delta^{18} \mathrm{O}$ diffused from north to west. Then, these factors met and mixed to gradually stabilize in Bosten Lake.

The isotope $\left(\delta^{18} \mathrm{O}\right)$ of Bosten Lake water exhibited an obvious change with the change in seasons (Figure 4). The average $\delta^{18} \mathrm{O}$ values of the Bosten Lake water were relatively high in summer (from June to August) but low in winter. The seasonal trends in $\delta^{18} \mathrm{O}$ of Bosten Lake water were consistent with the seasonal changes of the Kaidu River runoff [1], further proving that the Kaidu River is one of the main water sources recharging into Bosten Lake. However, the average $\delta^{18} \mathrm{O}$ value of Bosten Lake water $(-5.17 \%$ ) was increased compared with the river water (approximately $-11 \%$, [1]), especially in July, when the mean $\delta^{18} \mathrm{O}$ values of Bosten Lake and 


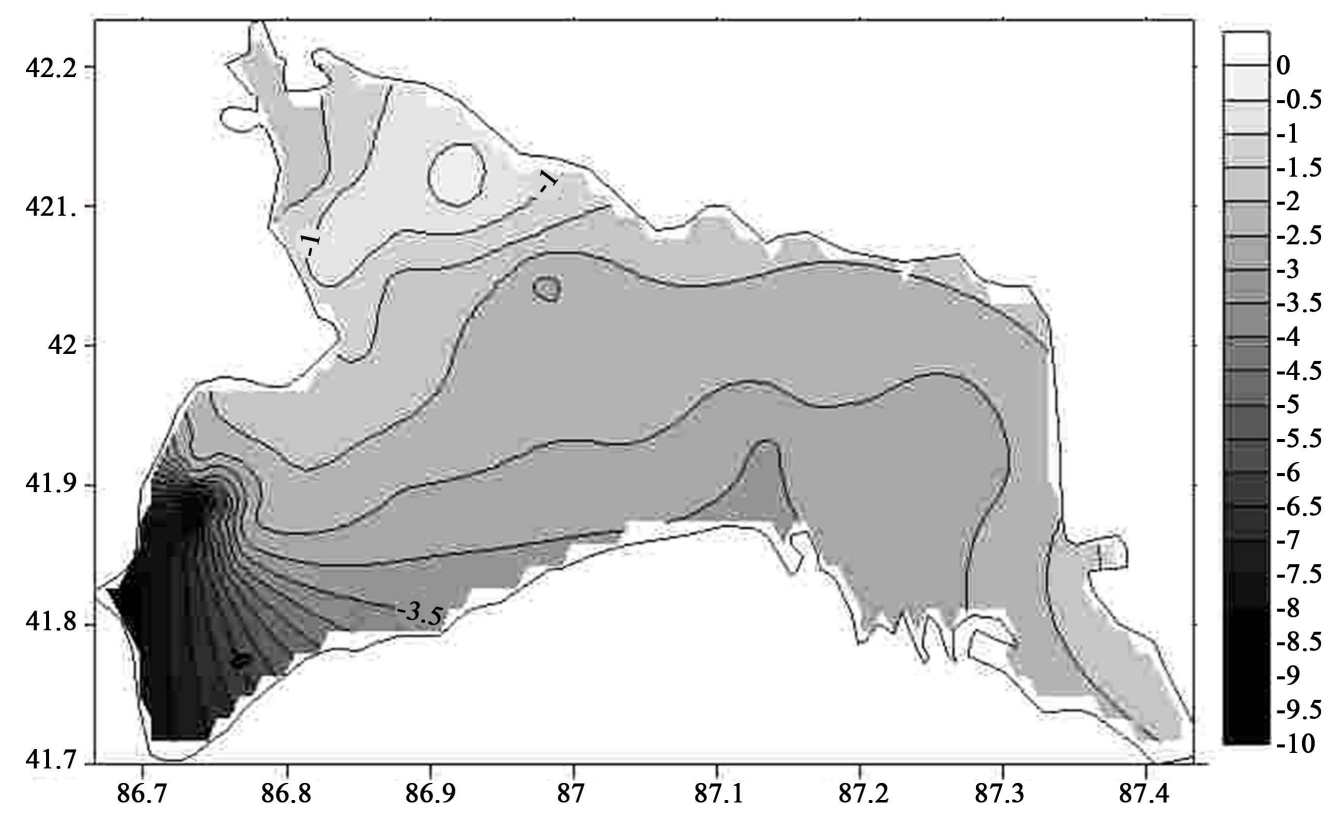

Figure 3. Spatial distribution of $\delta^{18} \mathrm{O}$ of Bosten Lake water.

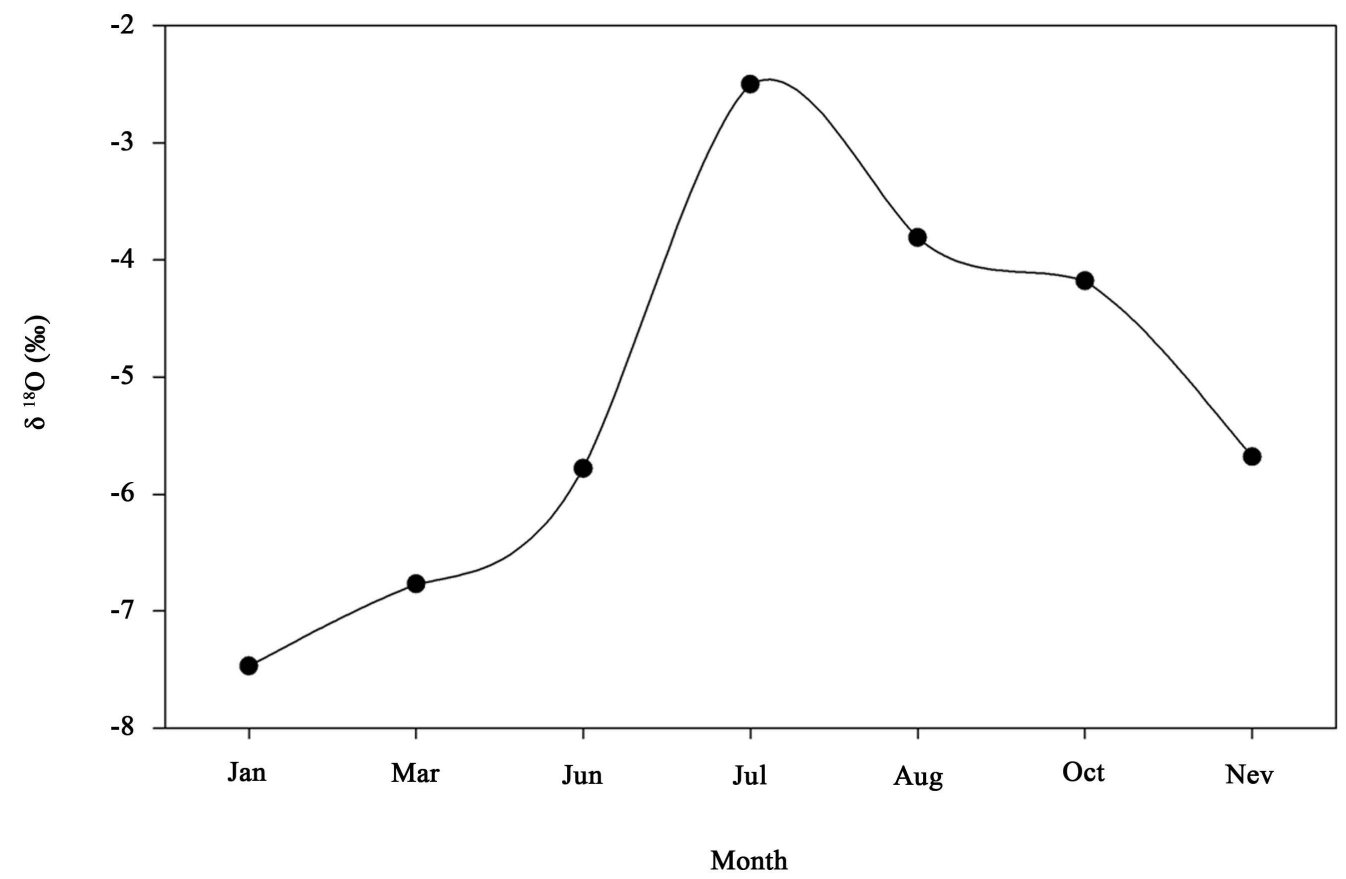

Figure 4. Temporal distribution of $\delta^{18} \mathrm{O}$ of Bosten lake water.

Kaidu River were $-2.50 \%$ and $-10.08 \%$, respectively. Combined with the analysis of the spatial and temporal distribution of $\delta^{18} \mathrm{O}$ in Bosten Lake water, these results indicate that the water cycle in the lake was very slow and that the evaporation was strong, resulting in the high $\delta^{18} \mathrm{O}$ of the lake water.

\subsection{Hydrograph Separation in Bosten Lake and Its Replenishment Rivers}

Isotope hydrograph separation is widely applied to quantify the replenishment of rivers for water resources management, especially in ungauged areas [21]. The distribution relationships between $\delta^{18} \mathrm{O}$ and TDS of the 
different water sources in the Kaidu River, the Huangshuigou River and Bosten Lake are presented in Figure 5. For the Kaidu River and Huangshuigou River, the alpine precipitation data were the mean values from the Bayinkuluke station located in the alpine mountain close to the base of the snow pack, the groundwater data were the mean values collected along the lower reaches of the Kaidu River and the Huangshuigou River, and the ice-snow-melt water data were collected from the Tianshan Mountain in Bayinbuluke. For Bosten Lake, the river water data were the mean values from the Kaidu River and Huangshuigou River water samples, the groundwater data were the mean values collected from Yanqi County located near Bosten Lake, the lake precipitation data were the means obtained from the Yanqi weather station, and the agricultural and industrial wastewater were collected from the main irrigation drainage channel. According to Figure 5, the water sources of the Kaidu River and Huangshuigou River runoff can be separated into three components as follows: ice-snow-melt water, alpine precipitation and groundwater; the water sources of Bosten Lake could be separated into four components as follows: river runoff, lake precipitation, groundwater, and irrigation and industrial drainage (wastewater). As shown in Figure 5, we can obtain the ratios of each component contributing to the Kaidu River, the Huangshuigou River and Bosten Lake based on Equation (3).

The results of hydrograph separation of the rivers and lake are presented in Table 1 . The ratios of ice-snowmelt water and groundwater, accounting for the majority of the Kaidu River, were $43 \%$ and $37 \%$, respectively. The ratios of alpine precipitation and ice-snow-melt water of the Kaidu River were increased compared with the Huangshuigou River. The reasons are because the birthplace of Kaidu River is the Hargat and Jacsta Valleys in the Sarming Mountains of Tianshan Mountains and because the river runoff was fed mainly by glacier melt and snowmelt from the alpine zone, as well as by precipitation from the mountain zone [22] [23].

Moreover, the water sources of the groundwater were similar to the runoff mainly originating from the seepage of ice-snow-melt water and alpine precipitation. However, the ratios of direct ice-snow-melt water and alpine precipitation of the Huangshuigou River diminished gradually due to the far distance from the mountains. Therefore, the groundwater, which was slowly recharged by the alpine precipitation and ice-snow melting in the mountain, accounted for a larger contribution. For Bosten Lake, groundwater and river runoff mainly accounted for $66 \%$ of the water sources forming the lake water, followed by wastewater and lake precipitation. Moreover, the groundwater had a similar replenishment as the river runoff. Therefore, both the rivers and lake in the

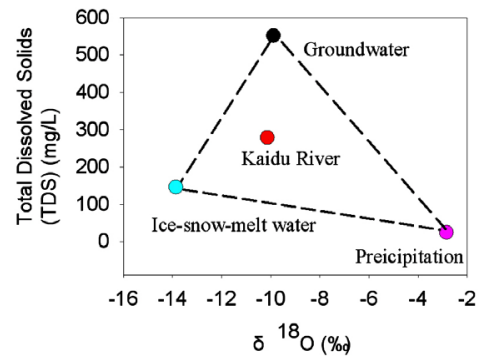

(a)

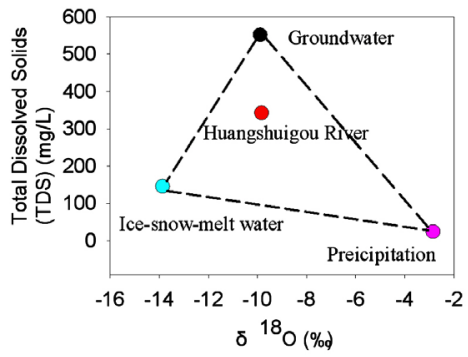

(b)

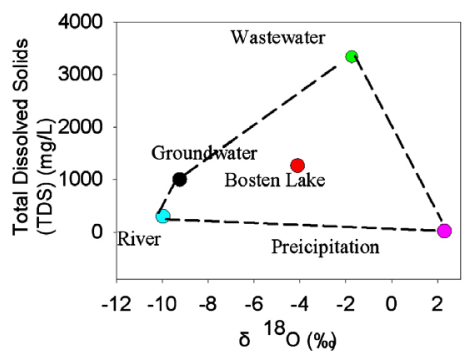

(c)

Figure 5. Relationships between $\delta^{18} \mathrm{O}$ and TDS of groundwater and surface water in the Kaidu River, the Huangshuigou River and Bosten Lake (the data are the means of the samples).

Table 1. Estimated fraction of water sources as a result of hydrograph separation in the Kaidu River, the Huangshuigou River and Bosten Lake.

\begin{tabular}{|c|c|c|c|c|}
\hline \multirow{2}{*}{ River } & & \multicolumn{3}{|c|}{ Estimated fraction (\%) } \\
\hline & & Precipitation & Groundwater & Ice-snow-melt water \\
\hline Kaidu River & & 20 & & 43 \\
\hline Huangshuigou River & & 8 & & 30 \\
\hline \multirow{2}{*}{ Lake } & \multicolumn{4}{|c|}{ Estimated fraction (\%) } \\
\hline & Precipitation & & Groundwater & Wastewater \\
\hline Bosten Lake & 9 & & 35 & 25 \\
\hline
\end{tabular}


Bosten Lake Basin are sensitive to the climate change of the local region. This finding is consistent with the results from analyzing the relationship of historic trends between climate variables and runoff [16]. Studies have indicated that the main factor causing Bosten Lake to gradually become a mild salt lake from a fresh lake was the irrigation and industrial wastewater drainage [24]-[26]. Our results provide further evidence using stable isotopes, proving that wastewater has significantly affected the TDS of Bosten Lake.

\subsection{Implications of Water Isotope Characteristics and Hydrograph Separation for Water Management in Bosten Lake}

\subsubsection{Predicting the Future Water Balance in Bosten Lake}

According to the isotope compositions $\left(\delta \mathrm{D}\right.$ and $\left.\delta^{18} \mathrm{O}\right)$ of the different water sources, the runoff in the Kaidu River and the Huangshuigou River, as well as the groundwater fall near the LMWL and GMWL, displaying similarity in the constitution of water sources recharged by precipitation and ice-snow-melt water in the alpine mountain. Therefore, both the Kaidu River and the Huangshuigou River depend on alpine precipitation and glacier snow, especially the Kaidu River, where ice-snow-melt water accounts for $43 \%$ of the river runoff. In addition, both rivers are sensitive to climate change. Seven hundred twenty-two glaciers covering approximately $445 \mathrm{~km}^{2}$ supply glacier melt water to the Kaidu River [23]. The snow surface area in the Kaidu River Basin declined significantly between 2000 and 2010 in both summer and winter [27]. Correlation analyses between climate variables and snow area have suggested that precipitation did not significantly affect snow area, but the air temperature was negatively correlated with the snow area [27]. Therefore, future warming may decrease Kaidu River runoff and hence Boston Lake inflows as: 1) large glaciers become thinner; 2) small and mid-sized glaciers disappear; and 3) snow lines recede with rising temperatures in the future [28].

Groundwater, which accounts for $35 \%$ of the water resources recharging to Bosten Lake, was another main contributor found using hydrograph separation. However, the groundwater recharging to Bosten Lake would also be reduced due to the expanding cultivated lands in the Kaidu River Basin. All of the cultivated lands rely on artificial irrigation in the Kaidu River Basin. From 1990 to 2010, cultivated land increased at a rate of 79.2 $\mathrm{km}^{2} / \mathrm{y}$ in the Kaidu-Kongqi River Basin [29]. A large amount of groundwater was diverted to agricultural irrigation due to the expanding croplands and limited surface water in the Kaidu River Basin. Six thousand groundwater wells were found along the Kaidu River when we collected the water samples.

In addition, the annual actual evaporative loss from Bosten Lake increased significantly between 1980 and 2011 [28], and the annual actual evaporation loss might increase with the warmer temperatures in the future. Hence, under future climate change, the inflow of Bosten Lake would be reduced, and the outflow may be increased due to the reduced runoff and groundwater and increased evaporation. The water volume and surface water level of Bosten Lake would be further decreased. Indeed, by the end of November 2012, the lower reaches of the Kaidu River were dry for a total of 32 days, including 12 consecutive days from 28 September to 9 October. The water level of Bosten Lake declined to $1045.25 \mathrm{~m}$ a.s.1.; this value was close to the threshold level (1045 m a.s.1.) below which the pumping systems in Bosten Lake cannot function. Further pumping from Bosten Lake into the Kongqi River below this threshold would dry out the wetland ecosystems around the lake, substantially affecting the fish and wildlife that depend on those wetlands.

\subsubsection{Future Water Management Strategies in Bosten Lake}

Bosten Lake was once one of the largest inland freshwater lakes in China, and its TDS was less than 1.0 g/L. However, the salinity of Bosten Lake has increased dramatically since the 1960s, and the mean TDS of Bosten Lake between 1980 and 2011 was $1.52 \mathrm{~g} / \mathrm{L}$ [28]. These higher TDS levels are considered slightly saline $(1 \leq$ TDS $<3 \mathrm{~g} / \mathrm{L}$ ) [30] and can be detrimental to agricultural production, drinking water quality, and lake ecology [31]. Irrigation drainage and industrial wastewater, which enriched high TDS, are the main factors affecting the water quality of Bosten Lake. Using hydrograph separation, we found that irrigation drainage and industrial waste water accounted for $25 \%$ of the water resources.

At the same time, the $\delta \mathrm{D}$ and $\delta^{18} \mathrm{O}$ of lake water, which are significant lower than the river water, lay below the LMWL, indicating that Bosten Lake experienced a very strong evaporation, especially in summer. Additionally, the spatial and temporal variability of the water isotopes in Bosten Lake indicate that the water cycle in the lake was very slow. These aggravated the accumulation of dissolved salts in the water body. Therefore, in future water resources management, both reducing the amount of wastewater and evaporation, as well as accelerating 
the water cycle should be given sufficient emphasis. There are two recommendations for future water management as follows: 1) local government should develop strict policies to restrict the sewage discharge into the lake to effectively reduce the amount of wastewater and basically improve the water quality of the lake; and 2) the pumping of water from Bosten Lake should be concentrated between May and September. Most Kaidu River runoff occurred during June, July and August, which occasionally results in summer floods [32]. In addition, high temperatures in the Bosten Lake Basin always occur from May to September. Moreover, the agricultural irrigation period also occurs from May to September in the Bosten Lake Basin. Therefore, diverting water to keep the Bosten Lake water levels low between May and September would not only ensure adequate irrigation water for crop growth in the Konqi River Basin but also decrease evaporative loss in the summer by reducing the water surface area and reducing flood risks [28]. Simultaneously, concentrating water diversions during a brief time period may accelerate the water circulation of the lake to discharge more salt water from the lake and improve the mixing of lake water with freshwater from the Kaidu River runoff, groundwater and lake precipitation, thus potentially reducing the overall salinity of the lake water.

\section{Conclusions}

Our study proves that stable isotope and hydrograph separation is a helpful method for analyzing the hydrology process and water balance in the inland lake, which is useful for the water resource management of rivers and lakes in arid regions. Our study draws attention to the following issues.

1) According to hydrograph separation, the Bosten Lake water comprised four components (river runoff, groundwater, irrigation drainage and industrial waste water, and local precipitation), with contributions of $31 \%$, $35 \%, 25 \%$ and $9 \%$, respectively.

2) According to the stable isotope ( $\delta \mathrm{D}$ and $\delta^{18} \mathrm{O}$ ) characteristics of the different water sources, slow water circulation and strong evaporation in the lake resulted in the high $\delta^{18} \mathrm{O}$ and TDS of the lake water. Irrigation drainage and industrial wastewater, enriched high TDS, were the main factors affecting the water quality of Bosten Lake.

3) The runoff in the Kaidu River and the Huangshuigou River, as well as groundwater, were located near the LMWL and GMWL, displaying a similarity in the constitution of water sources recharged by precipitation and ice-snow-melt water in the alpine mountain. Therefore, both the Kaidu River and Huangshuigou River depended on alpine precipitation and glacier snow, especially the Kaidu River, where the ice-snow-melt water accounted for $43 \%$ of the river runoff. In addition, both rivers are sensitive to climate change.

4) The Bosten Lake inflows would be reduced by the decrease in river runoff and groundwater under the future climate change trend. To improve water quality and reduce evaporative loss, the amount of wastewater should be strictly restricted by local government. In addition, water diversions from Bosten Lake should occur mainly between May and September.

\section{Acknowledgements}

This study was supported by the Natural Science Foundation of Xinjiang Uygur Autonomous Region (Grant No. 2014211A075).

\section{References}

[1] Wang, Y., Chen, Y.N. and Li, W.H. (2012) Temporal and Spatial Variation of Water Stable Isotopes $\left({ }^{18} \mathrm{O}\right.$ and $\left.{ }^{2} \mathrm{H}\right)$ in the Kaidu River Basin, Northweatern China. Hydrological Processes, 11, 95-104.

[2] Chen, Y., Ye, Z. and Shen, Y. (2011) Desiccation of the Tarim River, Xinjiang, China, and Mitigation Strategy. Quaternary International, 244, 264-271. http://dx.doi.org/10.1016/j.quaint.2011.01.039

[3] Fan, Y., Chen, Y., Li, X., Li, W. and Li, Q. (2014) Characteristics of Water Isotopes and Ice-Snowmelt Quantification in the Tizinafu River, North Kunlun Mountains, Central Asia. Quaternary International, 380, 116-122.

[4] Edwards, T.D.W., Bursey, G.G. and Prowse, T.D. (1993) Estimating Evaporation Using Stable Isotopes-Quantitative Results and Sensitivity Analysis for Two Catchments in Northern Canada. Nordic Hydrology, 24, 79-94.

[5] Lambs, L. (2004) Interactions between Groundwater and Surface Water in River Banks and the Confluence of Rivers. Journal of Hydrology, 288, 312-326. http://dx.doi.org/10.1016/j.jhydrol.2003.10.013

[6] Rock, L. and Mayer, B. (2007) Isotope Hydrology of the Oldman River Basin, Southern Alberta, Canada. Hydrologoc- 
al Processes, 21, 3301-3315. http://dx.doi.org/10.1002/hyp.6545

[7] Akiyama, T., Sakai, A., Yamazaki, Y., Wang, G. and Fujita, K. (2007) Surfacewater-Groundwater Interaction in the Heihe River Basin, Northwestern China. Bulletin of Glacier Research, 24, 87-94.

[8] Pang, Z., Huang, T. and Chen, Y. (2010) Diminished Groundwater Recharge and Circulation Relative to Degrading Riparian Vegetation in the Middle Tarim River. Hydrologuical Processes, 24, 145-157.

[9] Liu, Y., Fan, N., An, S., Bai, X., Liu, F., Xu, Z., Wang, Z. and Liu, S. (2008) Characteristics of Water Isotopes and Hydrograph Separation during the Wet Season in the Heishui River, China. Journal of Hyology, 353, 314-321. http://dx.doi.org/10.1016/j.jhydrol.2008.02.017

[10] Kong, Y. and Pang, Z. (2013) Evaluating the Sensitivity of Glacier Rivers to Climate Change Based on Hydrograph Separation of Discharge. China Academy of Sciences Institute of Geology and Geophysics, 2012 (12th) Academic Paper: Engineering Geology, 434-435, 121-129.

[11] Chen, J., Tang, C., Sakura, Y., Kondoh, A. and Shen, Y. (2002) Groundwater Flow and Geochemistry in the Lower Reaches of the Yellow River: A Case Study in Shandong Province, China. Hydrogeology Journal, 10, 587-599. http://dx.doi.org/10.1007/s10040-002-0231-7

[12] Tian, L., Yao, T., Sun, W., Stievenard, M. and Jouzei, J. (2001) Relationship between $\delta D$ and $\delta^{18} \mathrm{O}$ in Precipitation on North and South of the Tibetan Plateau and Moisture Recycling. Science in China Series D: Earth Sciences, 44, 789796. http://dx.doi.org/10.1007/BF02907091

[13] Craig, H. (1961) Isotopic Variations in Meteoric Waters. Science, 133, 1702-1703. http://dx.doi.org/10.1126/science.133.3465.1702

[14] Clark, I.D. and Fritz, P. (1997) Environmental Isotopes in Hydrogeology. Lewis Publishers, Boca Raton.

[15] Tian, L., Yao, T.D., MacClune, K., White, J.W.C. and Schilla, A. (2007) Stable Isotopic Variations in West China: A Consideration of Moisture Sources. Journal of Geophysical Research, Atmospheres, 112, 185-194. http://dx.doi.org/10.1029/2006jd007718

[16] Zhou, H., Li, W., Chen, Y. and Fu A. (2014) Water-Salt Succession Patterns (1951-2011) and Its Responses to Climate Change in Lake Bosten. Journal of Lake Sciences, 26, 55-65. (In Chinese with English abstract) http://dx.doi.org/10.18307/2014.0107

[17] Gibson, J.J., Birks, S.J. and Edwards, T.W.D. (2008) Global Prediction of $\delta_{\mathrm{A}}$ and $\delta^{2} \mathrm{H}-\delta^{18} \mathrm{O}$ Evaporation Slopes for Lakes and Soil Water Accounting for Seasonality. Global Biogeochemical Cycles, 22, 55-74. http://dx.doi.org/10.1029/2007GB002997

[18] Jonsson, C.E., Leng, M.J., Rosqvist, G.C., Seibert, J. and Arrowsmith, C. (2009) Stable Oxygen and Hydrogen Isotopes in Sub-Arctic Lake Waters from Northern Sweden. Journal of Hydrology, 376, 143-151. http://dx.doi.org/10.1016/j.jhydrol.2009.07.021

[19] Leng, M.J., Lamb, A.L., Heaton, T.H.E., Marshall, J.D., Wolfe, B.B., et al. (2006) Isotopes in Lake Sediments. In: Leng, M.J., Ed., Isotopes in Palaeoenvironmental Research, Springer Verlag, Dordrecht, 147-1846. http://dx.doi.org/10.1007/1-4020-2504-1_04

[20] Gao, J., Yao, T.D., Tian, L.D. and Liu, Y.Q. (2008) The Spacial Distribution of Oxygen Stable Isotope in the Yamzho Lake Basin, Xizang (Tibet). Journal of Glaciology and Geocryology, 30, 338-343. (In Chinese with English abstract)

[21] Immerzeel, W.W., Van Beek, L.P.H. and Bierkens, M.F.P. (2010) Climate Change Will Affect the Asian Water Towers. Science, 328, 1382-1385. http://dx.doi.org/10.1126/science.1183188

[22] Sun, Z.D. and Wang, R. (2006) Effect of Glaciers Change to Water Balance of Lake Bosten under Climatic Backgrounds. Journal of Lake Science, 18, 484-489. (In Chinese with English abstract) http://dx.doi.org/10.18307/2006.0507

[23] Ma, L.J., Zhao, J.F., Zhang, H.J., Fan, J.L. and Guo, X.Y. (2010) Impact of Glacier and Snow Melting on Bosten Lake under Climate Change. Arid Land Geography, 33, 210-216. (In Chinese with English abstract)

[24] Li, W.H. and Yuan, L. (2002) On the Water-Salt Change of Bosten Lake in Xinjiang. Journal of Lake Sciences, 14, 223-227. (In Chinese with English abstract)

[25] Gao, Y.F. and Yao, Y.F. (2005) Quantitative Effect of Human Activities on Water Level Change of Bosten Lake in Recent 50 Years. Scientia Geographica Sinica, 5, 305-309. (In Chinese with English abstract)

[26] Xie, G., Zhang, J., Tang, X., Cai, Y.A. and Gao G. (2011) Spatio-Temporal Heterogeneity of Water Quality (2010-2011) and Succession Patterns in Lake Bosten during the Past 50 Years. Gastroenterology, 23, 837-846. (In Chinese with English abstract)

[27] Li, Q., Li, L.H. and Bao, A.M. (2012) Snow Cover Change and Impact on Streamflow in the Kaidu River Basin. Resources Science, 34, 91-97. (In Chinese with English abstract)

[28] Zhou, H., Chen, Y., Perry, L. and Li, W. (2015) Implications of Climate Change for Water Management of an Arid In- 
land Lake in Northwest China. Lake and Reservoir Management, 31, 202-213. http://dx.doi.org/10.1080/10402381.2015.1062834

[29] Wang, Y., Chen, Y., Ding, J. and Fang, G. (2014) Land-Use Conversion and Its Attribution in the Kaidu-Kongqi River Basin, China. Quaternary International, 380-381, 216-223. http://dx.doi.org/10.1016/j.quaint.2014.10.010

[30] Li, W.H., Chen, Y.B. and Xu, H.L. (2003) A Study on Water Environmental Protection and Sustainable Utilization of Bosten Lake, Xinjiang. Geographical Research, 22, 185-191. (In Chinese with English abstract)

[31] Wang, C. (2007) Risk Degree Evaluation of Soil Salinization Based on GIS in Oasis Irrigated Area of Dry Inland River. Master's Thesis, Xinjiang Agriculture University, Urumqi.

[32] Chen, X., Wu, J.L. and Wang, L. (2005) Prediction of Climate Change Impacts on Stream Flow of Lake Bosten Using Artificial Neural Network Model. Journal of Lake Sciences, 17, 207-212. 